\title{
Alternative Estimates of Static and Dynamic Demand Systems for Canada
}

\author{
Richard Green; Zuhair A. Hassan; S. R. Johnson
}

American Journal of Agricultural Economics, Vol. 60, No. 1. (Feb., 1978), pp. 93-107.

Stable URL:

http://links.jstor.org/sici?sici=0002-9092\%28197802\%2960\%3A1\%3C93\%3AAEOSAD\%3E2.0.CO\%3B2-6

American Journal of Agricultural Economics is currently published by American Agricultural Economics Association.

Your use of the JSTOR archive indicates your acceptance of JSTOR's Terms and Conditions of Use, available at

http://www.jstor.org/about/terms.html. JSTOR's Terms and Conditions of Use provides, in part, that unless you have obtained prior permission, you may not download an entire issue of a journal or multiple copies of articles, and you may use content in the JSTOR archive only for your personal, non-commercial use.

Please contact the publisher regarding any further use of this work. Publisher contact information may be obtained at http://www.jstor.org/journals/aaea.html.

Each copy of any part of a JSTOR transmission must contain the same copyright notice that appears on the screen or printed page of such transmission.

The JSTOR Archive is a trusted digital repository providing for long-term preservation and access to leading academic journals and scholarly literature from around the world. The Archive is supported by libraries, scholarly societies, publishers, and foundations. It is an initiative of JSTOR, a not-for-profit organization with a mission to help the scholarly community take advantage of advances in technology. For more information regarding JSTOR, please contact support@jstor.org. 


\title{
Alternative Estimates of Static and Dynamic Demand Systems for Canada
}

\author{
Richard Green, Zuhair A. Hassan, and S. R. Johnson
}

Selected static and dynamic demand systems are applied to Canadian data for the period 1947-1972. Four commodity groups-durables, semi-durables, services and nondurables-are used for the major portion of the analysis. For the static systems, results for nine commodity groups are provided as a comparison. Income and price elasticity estimates, following from the static systems are, with the exception of the double log, proved reasonably similar. The estimates from the two dynamic systems, the dynamic linear expenditure and state adjustment models, appeared more plausible particularly for services and durable goods, where persistence in consumption patterns is generally observed. As related to other estimates from United States and Canadian data, these results seem to be more stable and more in agreement with a priori reasoning.

Key words: consumer demand, price and income elasticities, systems estimation.

While a substantial literature has developed on demand systems applications, few studies permit comparisons of results for the alternative specifications obtained from the same data base. Such comparisons are useful for a more complete understanding of consumer behavior as well as for evaluating the various demand systems models in an applied context. Static and dynamic forms of similar systems, results at different aggregation levels, and more complete comparisons with estimates from other studies afford a rich basis for evaluating the demand systems approaches.

This paper contains results of a comprehensive application of the major demand systems models to data on the Canadian economy. Annual observations for 1947-1972 are used as the data base. Estimates for three static and two dynamic systems are obtained using the data aggregated to four commodity groups. Two static and a double log system are also estimated for nine commodity groups. Results for the estimated models are then compared among themselves and to similar studies for Canada and the United States.

\footnotetext{
Richard Green is an assistant professor of agricultural economics, University of California, Davis; Zuhair A. Hassan is an economist with the Research Division, Economic Branch, Agriculture Canada, Ottawa; and S. R. Johnson is a professor of economics and agricultural economics, University of Missouri, Columbia.

Howard Howe, John Nash, William Tomek, and an anonymous reviewer provided very helpful comments on an earlier draft of this paper. Of course, the usual caveat applies regarding any errors which may remain.
}

The plan of the paper is as follows. First, a brief review of the static and dynamic demand systems is presented and the statistical assumptions on which the estimation methods are based are summarized. Then, the sample data and commodity groups are described. Next the results are discussed, and the performance of the models is evaluated. Finally, some concluding remarks based on the empirical results are offered.

\section{Demand Systems}

The purpose of this section is to set out the notation and examine the theoretical and behavioral implications of three static demand systems. As each of the systems is fully developed elsewhere, the derivations are omitted.

\section{Static Demand Systems}

Demand Functions Derived from Utility Maximization. Two widely used utility function-based approaches to demand systems estimation are the linear expenditure and the indirect addilog models. ${ }^{1}$ The linear expenditure system is derived from the utility function suggested by Klein and Rubin:

$$
u=\mu^{\prime} \log (q-\gamma),
$$

\footnotetext{
1 The extended linear expenditure system (Lluch, 1973) and flexible systems are other utility-function based approaches.
} 
where $\boldsymbol{q}=\left[\boldsymbol{q}_{i}\right]$ denotes an $n$-element column vector of quantities for the commodities, $\mu=$ $\left[\mu_{i}\right]^{\prime}$ is the $n$-component vector of marginal budget shares, and $\gamma=\left[\gamma_{i}\right]^{\prime}$ is a vector of elements to be interpreted as minimum required quantities. The parameters $\mu_{i}$ and $\gamma_{i}$ are estimated with the restrictions $0<\mu_{i},<1, \Sigma \mu_{i}$ $=1$, and $(q-\gamma)>0$. Maximizing this utility function subject to the budget constraint yields a system of demand functions

$$
\boldsymbol{q}=\boldsymbol{\gamma}+\left(\boldsymbol{m}-\boldsymbol{p}^{\prime} \gamma\right) \overline{\boldsymbol{p}}^{-1} \boldsymbol{\mu},
$$

where $\boldsymbol{p}=\left[p_{i}\right]$ is an $n$-element vector of commodity prices, $m$ is money income, and $\bar{p}$ denotes an $n \times n$ diagonal matrix, with nonzero elements given by the vector $p$ (Stone). These demand functions are homogeneous of degree zero in prices and income, satisfy the addingup criterion, and have a matrix of substitution terms that is symmetric and negative semidefinite (Yoshihara, p. 263).

Expenditure equations corresponding to the demand system (2) take the form

$$
p_{i} q_{i}=p_{i} \gamma_{i}+\mu_{i}\left(m-\Sigma_{j} p_{j} \gamma_{j}\right) \text {. }
$$

According to equation (3), the consumer may be viewed as purchasing minimum required quantities of each commodity, $\gamma_{i}$. At current market prices these quantities cost $\sum_{j} p_{j} \gamma_{j}$. The remainder of the available income $\left(m-\sum_{j} p_{j} \gamma_{j}\right)$ is then distributed over the commodities in fixed proportions, $\mu_{\mathrm{i}}$. Hence, $\sum_{j} p_{j} \gamma_{j}$ and $\left(m-\sum_{j} p_{j} \gamma_{j}\right)$ can be considered as "subsistence" and "supernumerary" incomes, respectively. ${ }^{2}$

The income $\left(\eta_{i}\right)$, own price $\left(e_{i i}\right)$, and cross price elasticities $\left(e_{i j}\right)$ can be calculated directly from equation (3). Expressions for the income and price elasticities, along with other information for comparing this and the demand systems to follow, are contained in table 1 . With $w_{i}=p_{i} q_{i} / m$ and $\mu_{i}>0$, all income elasticities are positive. For the own price elasticities, the conditions $0<\mu_{i}<1$ and $q_{i}-\gamma_{i}>0$ insure that the calculated values will be negative. Cross price elasticities are given by the expression $e_{i j}=-\mu_{i} /\left(p_{j} \gamma_{i} / p_{i} q_{i}\right)$. Clearly all are negative, unless some of the $\gamma_{i}^{\prime}$ 's are negative. Thus, both inferiority and complementarity are excluded, a consequence of the directly additive utility function.

Houthakker has derived a related demand

\footnotetext{
2 This interpretation holds when $\gamma_{i}$ is positive, a restriction not implicit in the specification of the system.
}

system using the indirect utility function. The indirect utility function specifies the maximum utility level for a given set of prices and a particular income

$$
u^{*}(\boldsymbol{p}, m)=\sum_{i} a_{i}\left(m / p_{i}\right)^{b}
$$

where $a_{i}$ and $b_{i}$ are parameters with $a_{i}<0, \Sigma a_{i}$ $=-1$, and $-1<b_{i}<0$. Explicit solutions for the demand functions can be obtained by differentiating equation (4) with respect to prices and income and applying Roy's identity. Equations in the resultant demand system are of the form

$$
\text { (5) } \begin{aligned}
q_{i}=\frac{a_{i} b_{i} m^{b_{i}} p_{i}^{-b_{i}-1}}{\sum_{j} a_{j} b_{j} m^{b} j^{-1} p_{j}^{-b j}} & \\
= & \frac{a_{i} b_{i}\left(\frac{m}{p_{i}}\right){ }^{1+b_{i}}}{\sum_{j} a_{j} b_{j}\left(\frac{m}{p_{j}}\right) b_{j}} .
\end{aligned}
$$

These demand functions are also homogeneous of degree zero in income and all prices, and satisfy the Engel aggregation and Slutsky symmetry conditions (Yoshihara, p. 264). Own price, cross price and income elasticities are easily obtained from equation (5) and shown in table 1. Since $-1<b_{i}<0, \eta_{i} \gtreqless 1$ according to whether $b_{i} \gtreqless \sum_{j} b_{j} w_{j}$. From the related expression for the own price elasticities observe that with $-1<b_{i}<0$ and $w_{i}>0$ they are bounded by minus one and zero. The cross price elasticities are obtained as $e_{i j}=b_{j} w_{j}$ and negative for admissable values of $b_{j}$. The cross price elasticities depend only on the commodity for which the price is changing.

A Demand System Specified Directly. The relative price version of the Rotterdam model Theil and Barten proposed is as follows (Barten 1964, 1968, 1969, 1977; and Theil 1967, 1971): $:^{3}$

$$
\text { (6) } \begin{aligned}
w^{*}{ }_{i t} \Delta\left(\ln q_{i t}\right) & =\sum_{j} b_{i j}\left[\Delta\left(\ln p_{j t}\right)\right. \\
& \left.-\sum_{k} \mu_{k} \Delta\left(\ln \mathrm{p}_{k t}\right)\right]+\mu_{i} \Delta\left(\ln \mathrm{q}_{t}\right),
\end{aligned}
$$

where $w^{*}{ }_{i t}=1 / 2\left(w_{i t}+w_{i t-1}\right), b_{i j}=\lambda p_{i} p_{j} \mu^{i j} / m$, $\mu_{\mathrm{i}}=p_{i}\left(\partial q_{i} / \partial m\right)$, the $\Delta$ 's denote changes between years and finally, $\lambda$ is the marginal utility of income, and $\mu^{i j}$ is the $i j^{\text {th }}$ element of the inverse of the Hessian matrix identified with

\footnotetext{
${ }^{3}$ Powell's (1966) system of additive preferences is also a demand system specified directly. Of the other static demand systems some, e.g., the double log, are inconsistent with restrictions imposed by the standard theory.
} 
Table 1. A Summary of Demand Systems Characteristics

\begin{tabular}{|c|c|c|c|c|c|c|c|c|}
\hline \multirow[b]{2}{*}{ Demand System } & \multirow[b]{2}{*}{$\begin{array}{c}\text { Utility } \\
\text { Function }\end{array}$} & \multirow[b]{2}{*}{$\begin{array}{l}\text { Functional } \\
\text { Form }\end{array}$} & \multicolumn{3}{|c|}{ Constraints } & \multicolumn{2}{|c|}{ Elasticities } & \multirow{2}{*}{$\begin{array}{l}\text { Number of } \\
\text { Parameters } \\
\text { Estimated }\end{array}$} \\
\hline & & & Engel & $\begin{array}{l}\text { Sym- } \\
\text { metry }\end{array}$ & $\begin{array}{l}\text { Homo- } \\
\text { geneity }\end{array}$ & $\begin{array}{c}\text { Income } \\
\left(\eta_{i}\right)\end{array}$ & $\begin{array}{c}\text { Price } \\
\left(e_{i i}\right)\end{array}$ & \\
\hline Linear Expenditure & $u=\mu^{\prime} \log (q-\gamma)$ & $\bar{p} \boldsymbol{q}=\bar{p} \gamma+(m-p \gamma) \mu$ & Holds & Holds & Holds & $\mu_{i} / w_{i}$ & $-1+\left(1-\mu_{i}\right) \frac{\gamma_{i}}{q_{i}}$ & $2 n$ \\
\hline Indirect Addilog & $u^{*}=\Sigma_{i} a_{i}\left(m / p_{i}\right)^{b_{i}}$ & $q_{i}=\frac{a_{i} b_{i}\left(m / p_{i}\right)^{1+b_{i}}}{\sum_{j} a_{j} b_{j}\left(m / p_{j}\right)^{b_{j}}}$ & Holds & Holds & Holds & $\left(1+b_{i}\right)-\Sigma_{j} b_{j} w_{j}$ & $-\left(1+b_{i}\right)+b_{i} w_{i}$ & $2 n$ \\
\hline Rotterdam & - & $\begin{array}{l}w^{*}{ }_{i t} \Delta\left(\ln q_{i t}\right)=\phi \mu_{i}\left[\Delta\left(\ln p_{i t}\right)\right. \\
\left.-\Sigma_{k} \mu_{k} \Delta\left(\ln p_{k t}\right)\right]+\mu_{i} \Delta\left(\ln q_{t}\right)\end{array}$ & Holds & Holds & Holds & $\mu_{i} / w_{i}$ & $\phi \eta_{i}-\eta_{i} w_{i}\left(1+\phi \eta_{i}\right)$ & $n+1$ \\
\hline Double-Logarithmic & - & $q_{i}=A_{i} m^{\eta} \Pi_{j} p_{j}^{\xi_{j}}$ & - & - & - & $\eta_{i}$ & $e_{i i}$ & $n^{2}+n$ \\
\hline State Adjustment & - & $q_{i}=\theta_{i}+\alpha_{i} s+\kappa_{i} m+\nu_{i} p$ & - & - & - & $(\mathrm{SR}) \kappa_{i} \frac{m}{q_{i}}$ & (SR) $\nu_{i} \frac{p_{i}}{q_{i}}$ & $5 n$ \\
\hline $\begin{array}{l}\text { Linear Expenditure } \\
\text { (Dynamic) }\end{array}$ & $u=\mu^{\prime} \log (q-\theta-\bar{\alpha} s)$ & $\begin{array}{c}q=(\theta+\bar{\alpha} s)+\left(\iota^{\prime} \mu\right)^{-1} \bar{p}^{-1} \\
\mu\left(m-p^{\prime}(\theta+\bar{\alpha} s)\right)\end{array}$ & Holds & Holds & Holds & $\begin{array}{l}\text { (LR) } \frac{\kappa_{i} \delta_{i}}{\delta_{i}-\alpha_{i}} \frac{m}{q_{i}} \\
\text { (SR) } \mu_{i} /\left(\Sigma \mu_{i}\right) w_{i} \\
\text { (LR) } \mu^{*}{ }_{i} / w_{i}\end{array}$ & $\begin{array}{c}\text { (LR) } \frac{\nu_{i} \delta_{i}}{\delta_{i}-\alpha_{i}} \cdot \frac{p_{i}}{q_{i}} \\
(\mathrm{SR}) \phi \eta_{i}-\eta_{i} w_{i}\left(1+\phi \eta_{i}\right) \\
(\mathrm{LR})-1+\left(1-\mu^{*}{ }_{i}\right) \frac{\gamma^{*}{ }_{i}}{q_{i}}\end{array}$ & $4 n$ \\
\hline
\end{tabular}


the second-order conditions of the consumer maximization problem. When the additivity condition is imposed, the demand equation (6) can be simplified to

$$
\begin{aligned}
w^{*}{ }_{i t} \Delta\left(\ln q_{i t}\right) & =\phi \mu_{i}\left[\Delta\left(\ln p_{i t}\right)\right. \\
& \left.-\sum_{k} \mu_{k} \Delta\left(\ln p_{k t}\right)\right]+\mu_{i} \Delta\left(\ln q_{t}\right)
\end{aligned}
$$

where $\phi$ is the reciprocal of Frisch's money flexibility $\left(\omega=\frac{\partial \lambda}{\partial m} \frac{m}{\lambda}\right)$. In this form the demand functions contain only $n+1$ parameters, the $\mu_{i}$ and $\phi$.

As shown in table 1, the income elasticities are given by ratios $\mu_{i} / w_{i}$ and thus restricted to be positive. Also, the commodity group is income elastic or inelastic, depending upon the inequality, $\mu_{i} \gtreqless w_{i}$. The own price elasticity expression can take both positive and negative values. The cross price elasticity is $e_{i j}=\left(b_{i i} \mu_{j}\right.$ $\left.-w_{j} \mu_{i}\right) w_{i}$. These expressions for the price elasticities can be simplified; that is, $e_{i i}=\phi \eta_{i}$ $-\eta_{i} w_{i}\left(1+\phi \eta_{i}\right)$ and $e_{i j}=-\eta_{i} w_{j}\left(1+\phi \eta_{j}\right)$, in the case of additive preferences (i.e., for $b_{i i}=$ $\left.\phi \eta_{i}\right)$. From the simplified expressions it follows that $e_{i j} \gtreqless 0$, according to $\left|\eta_{i} w_{j} \phi \eta\right| \gtreqless$ $\left|\eta_{i} w_{j}\right|$. For example, if $\left|\eta_{i} w_{j}\right|>\left|\eta_{j} w_{j} \phi \eta_{i}\right|$, then $e_{i j}<0$ and the cross price elasticity reflects the income effect rather than the substitution effect of the price change.

\section{Dynamic Demand Systems}

The first of the two "dynamic" systems reviewed is the state adjustment model of Houthakker and Taylor. ${ }^{4}$ The state adjustment model at time $t$ can be expressed as

$$
q_{i t}=\theta_{i}+\alpha_{i} s_{i t}+\kappa_{i} m_{t}+\nu_{i} p_{i t}
$$

where $q_{i t}$ is the (rate of) demand, $m$ is the rate of income, $p_{i t}$ is the relative price, $s_{i t}$ is the stock of the commodity and may be viewed either as a physical stock (in case of durable goods) or psychological stock of habits (in case of habit-forming goods), and $\theta_{i}, \alpha_{i}, \kappa_{i}$, and $\nu_{i}$ are the underlying structural parameters. According to the interpretation of the model, $\alpha_{i}>0$ for habit-forming goods and $\alpha_{i}<$ 0 for durable goods. It is further assumed that

$$
\dot{s}_{i}=q_{i t}-\delta_{i} s_{i t},
$$

where $\dot{s}_{i}$ denotes the rate of change in stock,

\footnotetext{
4 Intertemporal demand systems developed by Phlips (1974) and Lluch (1974) are recent attempts at specifying more completely dynamic demand models.
}

$d s_{i t} / d t$, and $\delta_{i}$ is a constant depreciation rate, normally taken to be positive.

For empirical implementation, the unobservable variable $s_{i t}$ is eliminated by combining equations (8) and (9). After differentiation of the resulting expression with respect to time and using the discrete approximation $\dot{s}_{i}=s_{i t}$ $s_{i t-1}$ and $s_{i t}=1 / 2\left(s_{i t}+s_{i t-1}\right)$ and suppressing the commodity subscripts $(i)$ for the parameters, the model is

$$
\begin{aligned}
\text { (10) } q_{i t}=\frac{\theta \delta}{1-1 / 2(\alpha-\delta)} & \\
+\frac{1+1 / 2(\alpha-\delta)}{1-1 / 2(\alpha-\delta)} q_{i t-1} & +\frac{\kappa(1+1 / 2 \delta)}{1-1 / 2(\alpha-\delta)} \Delta m_{t} \\
+ & \frac{\kappa-\delta}{1-1 / 2(\alpha-\delta)} m_{t-1}+\frac{\nu(1+1 / 2 \delta)}{1-1 / 2(\alpha-\delta)} \Delta p_{i t} \\
& +\frac{\nu \delta}{1-1 / 2(\alpha-\delta)} p_{i t-1},
\end{aligned}
$$

or in more convenient form,

$$
\begin{aligned}
q_{i t}=A_{i 0} & +A_{i 1} q_{i t-1}+A_{i 2} \Delta m_{t} \\
& +A_{i 3} m_{t-1}+A_{i 4} \Delta p_{i t}+A_{i 5} p_{i t-1} .
\end{aligned}
$$

The $A$ 's along with the condition $A_{i 2} A_{i 5}=$ $A_{i 3} A_{i 4}$ can be solved for unique values of the underlying structural parameters.

The short-run derivatives of consumption with respect to income and price are given by $\kappa_{i}$ and $\nu_{i}$, respectively. Long-run derivatives are obtained by assuming $\dot{s}_{i}$ as shown in equation (9) equal to zero, implying that the stock adjustment has reached an equilibrium state. Substitution of the resulting expression into equation (8) gives

(12) $q_{i t}=\frac{\theta_{i} \delta_{i}}{\delta_{i}-\alpha_{i}}+\frac{\kappa_{i} \delta_{i}}{\delta_{i}-\alpha_{i}} m_{t}+\frac{\nu_{i} \delta_{i}}{\delta_{i}-\alpha_{i}} p_{i t}$.

For $\delta_{i} \neq \alpha_{i}$, the long-run derivatives of consumption with respect to income and price are given by coefficients of $m_{t}$ and $p_{i t}$, respectively. Expressions for elasticities based on these coefficients of the long- and short-run forms of the demand functions are shown in table 1.

The second dynamic model to be applied is due Phlips (1972). It is a dynamic version of the linear expenditure system and can be developed by assuming that the elements of the parameter vector $\gamma$ are linear functions of state variables

$$
\gamma=\boldsymbol{\theta}+\bar{\alpha} s_{t},
$$

where $s_{t}=\left[s_{i t}\right]^{\prime}, \theta=\left[\theta_{i}\right]^{\prime}$ and $\alpha=\left[\alpha_{i}\right]^{\prime}$ are vectors of constants which may take positive 
or negative values. An adjustment equation identical to (9) but in vector notation is used, i.e., $\dot{s}=q_{t}-\bar{\delta} s_{t}$ with $\dot{s}=\left[\dot{s}_{i}\right]^{\prime}, \delta=\left[\delta_{i}\right]^{\prime}$, and $\delta$ is a diagonal matrix with nonzero elements $\delta_{i}$.

Substitution of equation (13) for $\gamma$ in equation (1) and maximization of the utility function subject to the budget constraint yields short-run demand functions of the form

$$
\begin{aligned}
q_{i t}=\left(\theta_{i}+\alpha_{i} s_{i t}\right) & +\frac{\mu_{i}}{p_{i t}\left(\Sigma \mu_{i}\right)} \\
& {\left[m_{t}-\Sigma_{j} p_{j t}\left(\theta_{j}+\alpha_{j} s_{j t}\right)\right] . }
\end{aligned}
$$

Again, the corresponding long-run demand equations are derived on the assumption $\dot{s}=0$. Using this result equation (14) becomes

$$
q^{*}{ }_{i t}=\gamma^{*}{ }_{i t}+\frac{\mu_{i}^{*}}{p_{i t}}\left(m_{t}-\Sigma_{j} p_{j t} \gamma_{j}^{*}\right)
$$

where

$$
\gamma_{i}^{*}=\frac{\gamma_{i} \theta_{i}}{\delta_{i}-\alpha_{i}}
$$

and

$$
\mu^{*}{ }_{i}=\frac{\delta_{i} \mu_{i} /\left(\gamma_{i}-\alpha_{i}\right)}{\Sigma_{j} \delta_{j} \mu_{j} /\left(\delta_{j}-\alpha_{j}\right)}
$$

Here, $\gamma^{*}{ }_{i}$ is the long-run counterpart of the short-run parameter, $\theta_{i}, \gamma^{*}>\theta_{i}$ when $\alpha_{i}>0$, i.e., commodity $i$ is habit forming, and $\gamma^{*}{ }_{i}<\theta_{i}$ when $\alpha_{i}<0$, i.e., commodity $i$ is durable; and finally, $\mu^{*}{ }_{i}$ is the long-run marginal budget share satisfying the condition $\Sigma_{i} \mu_{i}{ }_{i}=1$.

From equations (14) and (15) the short-run and long-run demand elasticities can be derived (table 1). For this purpose, in the shortrun it is assumed $\partial s_{i t} / \partial m_{t}=0$. The expressions are of the same form as those obtained for the static linear expenditure system. However, the estimated values for the parameters are different, owing to the added structure provided by the dynamic adjustment mechanism. Finally, for empirical work, the unobservable state variables $s_{i t}$ are eliminated and the data are differenced to approximate instantaneous time rates of change. Making these adjustments in equation (14), the demand system becomes

$$
\begin{aligned}
& \text { (16) } q_{i t}=\frac{2 \delta_{i} \theta_{i}}{2-\alpha_{i}+\delta_{i}}+\frac{2+\alpha_{i}-\delta_{i}}{2-\alpha_{i}+\delta_{i}} q_{i t-1} \\
& +\frac{\mu_{i}\left(\delta_{i}+2\right)}{2-\alpha_{i}+\delta_{i}} \frac{1}{\lambda_{t} p_{i t}}+\frac{\mu_{i}\left(\delta_{i}-2\right)}{2-\alpha_{i}+\delta_{i}} \frac{1}{\lambda_{t-1} p_{i t-1}}
\end{aligned}
$$

$$
\begin{aligned}
q_{i t}=k_{i 0}+k_{i 1} q_{i t-1}+k_{i 2} & \frac{1}{\lambda_{t} p_{i t}} \\
& +k_{i 3} \frac{1}{\lambda_{t-1} p_{i t-1}} .
\end{aligned}
$$

Structural coefficients for the dynamic linear expenditure system can be unambiguously calculated from the estimated regression coefficients for equation (17).

\section{A Synthesis}

Table 1 includes information on the utility function assumed (where appropriate), the functional form of the demand equation, an indication of whether or not the constraints imposed by the classical theory are satisfied, and the number of parameters to be estimated. Thus, it is a reference for evaluating alternative empirical demand systems. Of course, there are advantages and disadvantages to each approach. The important point is that each has certain theoretical and empirical implications which should be reflected in interpreting the applied results.

\section{Estimation Methods}

For empirical implementation, normal, additive error terms were included in the specifications for the linear expenditure and indirect addilog demand systems. These error terms were assumed to have zero means, contemporaneous variance-covariance matrix $\Omega$, and to be intertemporally uncorrelated. Due to the adding-up criterion, the variance-covariance matrix is singular. When no autocorrelation exists, this singularity problem can be handled by arbitrarily deleting an equation from the system (Berndt and Savin). The resulting system has a positive definite contemporaneous variance-covariance matrix of full rank (Parks, Carlevaro and Sadoulet). The omitted equation as well as the full covariance estimator $\Omega$, are then obtained by applying the Engel aggregation condition. ${ }^{5}$

For the Rotterdam model the estimation procedure of Barten and Theil is utilized. The stochastic nature of the demand equations is rationalized on the basis of a randomness associated with changes in the underlying utility

\footnotetext{
${ }^{5}$ The choice of this method was based largely on the availability of a specialized program for obtaining maximum likelihood estimates of the parameters for the linear expenditure and the indirect addilog systems (Carlevaro and Sadoulet).
} 
function. These changes are assumed to be independent of income and prices. If it is assumed that this source of randomness is confined to the linear term in a quadratic approximation of the underlying utility function, then the stochastic component of consumption can be taken as an additive term in the demand functions. When this term is added along with the properties which derived from the assumptions implied by the model, an iterative leastsquares procedure can be employed to approximate the optimal estimators.

The dynamic linear expenditure system and state adjustment model are modified to include additive error terms with the usual properties required for application of ordinary least squares. For the dynamic linear expenditure system, an iterative procedure (method D) suggested by Houthakker and Taylor (p. 202) is used. Initial values for $\lambda_{t}$ are selected and ordinary least squares is applied to estimate the remaining parameters. Then, from the estimates of the coefficients obtained in step one, a new set of values for $\lambda_{t}$ is obtained by making the calculation shown in Phlips (1974, p. 192). The process continues until the budget constraint is approximately satisfied for each time period. The state adjustment model was estimated using a non-linear least squares procedure under the aforementioned restrictions, $A_{i 2} A_{i 5}=A_{i 3} A_{i 4}$.

\section{Data Sources and Commodity Groupings}

Time-series (1947-1972) data on annual personal consumption expenditures and prices are used in estimating the parameters required for the demand systems to be studied. Personal consumption expenditure data for major commodity groups and services are based on official estimates of Statistics Canada. The other data required, implicit price indexes $(1971=100)$ for the commodity groups, are also available from the same source. The price indexes are derived by dividing expenditure in current dollars by expenditure in constant dollars and are called implicit deflators. That is, the weights of the various components in the commodity groups shift with the changing composition of commodities or services over time. Finally, the population data used to obtain the per capita variables required for the analysis are for the mid-year (June 1) and available from Statistics Canada.

For the linear expenditure and the indirect addilog systems, the expenditure data $\left(p_{i t} q_{i t}\right)$ is per capita current dollar personal expenditure on the $i^{\text {th }}$ commodity. The price series $\left(p_{i t}\right)$ are implicit and indexed $(1971=100)$. Income $(m)$ is measured, using the per capita total personal expenditure in current dollars.

In the Rotterdam model a simple procedure was used to obtain the observations on the dependent variables. First, logarithms of the total quantities demanded were calculated, using $\ln q_{i t}=\ln \left(p_{i t} q_{i t}\right)-\ln p_{i t}$. Next, the logarithm in midyear population was subtracted from the logarithm of quantity for each year, to obtain per capita quantity demanded. Finally, first differences were calculated and then multiplied by the average expenditure proportions. The income (total expenditure) variable in the Rotterdam model is derived as a sum of the values for the dependent variables.

In the state adjustment model, the quantity data $\left(q_{i t}\right)$ are per capita constant (1971) dollar expenditures on the $i^{t h}$ commodity. The price series are relative and obtained by dividing expenditure in current dollars by expenditure in constant dollars for each commodity group, and by deflating the results by the implicit price index for total personal expenditure on consumer goods and services. The income variable $\left(m_{t}\right)$ is the total personal expenditure in constant dollars per capita. Finally, in the case of the dynamic linear expenditure system, the quantity data are in constant dollars. The price series $\left(p_{i t}\right)$ are implicit, and income $\left(m_{t}\right)$ is total expenditure in current dollars per capita.

The major application of the demand systems models is to consumer expenditures aggregated into four groups: durable goods, semi-durable goods, nondurable goods, and services. These groups are mutually exclusive, account for the total expenditures of consumers, and follow principles of classification used by Statistics Canada. For comparison, two static systems and the double log model are applied for nine commodity groups. The classification in this case is by function and not type of good and again follows the classification system used by Statistics Canada.

\section{Results}

The major results for the models estimated using four commodity groups are reported first 
Table 2. Basic Parameter Estimates for the Static Demand Systems

\begin{tabular}{|c|c|c|c|c|c|c|c|}
\hline \multirow[b]{2}{*}{ Commodity Group } & \multicolumn{2}{|c|}{ Rotterdam Model } & \multicolumn{2}{|c|}{$\begin{array}{c}\text { Linear Expenditure } \\
\text { System } \\
\end{array}$} & \multicolumn{3}{|c|}{ Indirect Addilog System } \\
\hline & $\begin{array}{c}\text { Price } \\
\text { Coefficient } \\
b_{i i} \\
\end{array}$ & $\begin{array}{c}\text { Marginal } \\
\text { Budget } \\
\text { Share } \\
\mu_{i} \\
\end{array}$ & $\begin{array}{c}\text { Minimum } \\
\text { Required } \\
\text { Quantity } \\
\gamma \\
\end{array}$ & $\begin{array}{c}\text { Marginal } \\
\text { Budget } \\
\text { Share } \\
\mu_{i} \\
\end{array}$ & $c_{i}$ & $b_{i}$ & $\begin{array}{c}\text { Marginal } \\
\text { Budget } \\
\text { Share }^{b}\end{array}$ \\
\hline Durable Goods & $\begin{array}{l}-.1799 \\
(.0571)^{\mathrm{a}}\end{array}$ & $\begin{array}{l}.2331 \\
(.0323)\end{array}$ & $\begin{array}{l}10.32 \\
(4.21)\end{array}$ & $\begin{array}{l}.1844 \\
(.0151)\end{array}$ & $\begin{array}{l}.0999 \\
(.0073)\end{array}$ & $\begin{array}{l}-.1539 \\
(.1334)\end{array}$ & .1934 \\
\hline Semidurable Goods & $\begin{array}{c}-.0931 \\
(.0370)\end{array}$ & $\begin{array}{l}.1207 \\
(.0226)\end{array}$ & $\begin{array}{r}167.12 \\
(2.70)\end{array}$ & $\begin{array}{l}.0836 \\
(.0052)\end{array}$ & $\begin{array}{l}.1878 \\
(.0065)\end{array}$ & $\begin{array}{l}-.9665 \\
(.1793)\end{array}$ & .0853 \\
\hline Nondurable Goods & $\begin{array}{l}-.1764 \\
(.0448)\end{array}$ & $\begin{array}{l}.2287 \\
(.0306)\end{array}$ & $\begin{array}{r}333.60 \\
(6.59)\end{array}$ & $\begin{array}{l}.2373 \\
(.0122)\end{array}$ & $\begin{array}{l}.3956 \\
(.0166)\end{array}$ & $\begin{array}{l}-.8280 \\
(.1572)\end{array}$ & .2524 \\
\hline Services & $\begin{array}{c}-.3221 \\
(.0993) \\
\end{array}$ & $\begin{array}{l}.4175 \\
(.0486) \\
\end{array}$ & $\begin{array}{c}46.88 \\
(24.23) \\
\end{array}$ & $\begin{array}{c}.4947 \\
(.0293) \\
\end{array}$ & $\begin{array}{r}.3167 \\
(.0279) \\
\end{array}$ & $\begin{array}{c}-.3083 \\
(.2870) \\
\end{array}$ & .4689 \\
\hline Income Flexibility $\phi$ & $\begin{array}{c}-.7715 \\
(.2162)\end{array}$ & & & & & & \\
\hline
\end{tabular}

a Standard errors are in parentheses.

${ }^{\mathrm{b}}$ Calculated as the income elasticity multiplied by the expenditure share.

for the static systems and then for the dynamic systems.

\section{Static Systems: Basic Parameter Estimates}

Estimates of the parameters for the three static systems are presented in table 2 . Referring first to those for the Rotterdam model, all the values for the coefficients are more than twice their estimated standard errors. The parameter estimates are also consistent with the qualitative restrictions implied by the behavioral assumptions and model structure. The estimated income flexibility coefficient $(\phi)$ is equal to -0.77 . This implies that the marginal utility of income decreases by $1.30 \%$ in response to a $1 \%$ increase in income. The value is similar to the one $(-1.55)$ reported by Powell (1965). Furthermore, this value $(-1.30)$ lies between Frisch's (p. 189) money flexibility of -2 for the median part of the population and -0.7 for the better-off part of the population.

For the linear expenditure system, the estimated marginal budget shares are all positive, significantly different from zero on a statistical basis, and sum to 1 . The estimated $\gamma_{i}$ 's represent minimal consumption levels for the various commodities and, as expected, are positive and range from 333.60 for nondurable goods to 10.32 for durable goods. Finally, the basic parameter estimates for the indirect addilog system appear to be as reliably estimated as those for the other systems shown in table
2. Additionally, the results are consistent with a priori reasoning. That is, all the estimates of the $b_{i}$ 's are negative and lie within the interval $(-1,0)$. Likewise, all of the estimates of $c_{i}=$ $a_{i} b_{i}$ are positive, as expected, and sum to 1 .

For the three systems, variations in the estimated marginal budget shares are not substantial. Specifically, the results suggest that the budget shares for durables, semidurables, nondurables, and services are near $.20, .10$, .25 , and .45 , respectively. The stability of these parameters across systems specifications and estimation methods is encouraging for the appropriateness of commodity groupings, the separability assumptions, and more generally, the robustness of the results.

\section{Static Systems: Elasticities}

Income elasticities, direct price elasticities (compensated and uncompensated), and expenditure shares for the Rotterdam, linear expenditure, and indirect addilog systems are presented in table 3. All the income elasticities are positive, ranging from 1.69 for durables estimated from the Rotterdam model to .58 for semidurables for the linear expenditure model, indicating that the commodity groups are not inferior. This result is not surprising given the level of aggregation in the commodity groupings. The durable goods and services groups have estimated income elasticities which are greater than one. This implies that the commodities they contain include lux- 
Table 3. Comparison of Elasticities Estimated from the Parameters for the Static Demand Systems

\begin{tabular}{|c|c|c|c|c|c|c|c|c|c|c|}
\hline \multirow[b]{3}{*}{$\begin{array}{l}\text { Commodity } \\
\text { Group }\end{array}$} & \multirow[b]{3}{*}{$\begin{array}{c}\text { Expen- } \\
\text { diture } \\
\text { Share } \\
\end{array}$} & \multicolumn{3}{|c|}{ Income Elasticity } & \multicolumn{6}{|c|}{ Direct Price Elasticity } \\
\hline & & \multirow[b]{2}{*}{$\begin{array}{c}\text { Rotter- } \\
\text { dam }\end{array}$} & \multirow[b]{2}{*}{$\begin{array}{l}\text { Linear } \\
\text { Expen- } \\
\text { diture }\end{array}$} & \multirow[b]{2}{*}{$\begin{array}{l}\text { Indirect } \\
\text { Addilog }\end{array}$} & \multicolumn{3}{|c|}{ Uncompensated } & \multicolumn{3}{|c|}{ Compensated } \\
\hline & & & & & $\begin{array}{c}\text { Rotter- } \\
\text { dam }\end{array}$ & $\begin{array}{c}\text { Linear } \\
\text { Expen- } \\
\text { diture }\end{array}$ & $\begin{array}{l}\text { Indirect } \\
\text { Addilog }\end{array}$ & $\begin{array}{c}\text { Rotter- } \\
\text { dam }\end{array}$ & $\begin{array}{l}\text { Linear } \\
\text { Expen- } \\
\text { diture }\end{array}$ & $\begin{array}{l}\text { Indirect } \\
\text { Addilog }\end{array}$ \\
\hline $\begin{array}{l}\text { Durable Goods } \\
\text { Semidurable }\end{array}$ & 0.1375 & 1.69 & 1.34 & 1.40 & -1.23 & -0.96 & -0.86 & -1.00 & -0.77 & -0.67 \\
\hline $\begin{array}{l}\text { Goods } \\
\text { Nondurable }\end{array}$ & 0.1435 & 0.84 & 0.58 & 0.59 & -0.69 & -0.44 & -0.17 & -0.57 & -0.36 & -0.08 \\
\hline $\begin{array}{l}\text { Goods } \\
\text { Services }\end{array}$ & $\begin{array}{l}0.3446 \\
0.3744\end{array}$ & $\begin{array}{l}0.66 \\
1.11\end{array}$ & $\begin{array}{l}0.68 \\
1.32\end{array}$ & $\begin{array}{l}0.73 \\
1.25\end{array}$ & $\begin{array}{l}-0.62 \\
-0.91\end{array}$ & $\begin{array}{l}-0.59 \\
-0.96\end{array}$ & $\begin{array}{l}-0.45 \\
-0.80\end{array}$ & $\begin{array}{l}-0.39 \\
-0.50\end{array}$ & $\begin{array}{l}-0.35 \\
-0.47\end{array}$ & $\begin{array}{l}-0.20 \\
-0.33\end{array}$ \\
\hline
\end{tabular}

uries; that is, goods for which expenditures increase more than proportionately with income. Alternatively, the semidurable and nondurable commodity groups have estimated elasticities which are less than one. This implies that the commodities of which they are composed are largely necessities. Consumption of such items tends to remain relatively stable irrespective of income levels.

Differences among the estimates obtained using the three systems are in some cases sizable. Generally, the estimates from the linear expenditure and indirect addilog systems compare more closely. The Rotterdam model produces notably higher income elasticity estimates for the durable goods and semidurable goods groups and a lower estimate for the services group. For example, in the case of durable goods, the income elasticity estimate for the Rotterdam model is 1.69 , as contrasted with values of 1.34 and 1.40 for the linear expenditure and indirect addilog models, respectively.

The compensated price elasticity estimates are substantially lower than the uncompensated estimates. Generally, durable goods and services groups have price elasticities closer to -1 . For durable goods, the range in uncompensated price elasticity estimates is from -1.23 for the Rotterdam model to -.86 for the indirect addilog model. In the case of services, a similar comparison shows a high value of -.96 for the linear expenditure system and a low value of -.80 for the indirect addilog model. The durables and services groups are composed of commodities that tend to be more price elastic. For the semidurable goods, the results are more variable, ranging from -.17 for the indirect addilog system to
-.69 for the Rotterdam system. Aside from this result, the estimates from the three systems are rather similar. Price elasticities from the Rotterdam model are, in general, the highest. In fact, the one exception is for services in the linear expenditure system. The lowest price elasticity estimates are for the indirect addilog system.

\section{Dynamic Systems: Basic Parameter Estimates}

Estimates of the basic parameters for the state adjustment model are reported in table 4 . Most of the parameter estimates are statistically significant at the $5 \%$ level. A priori restrictions on these basic parameter estimates, following from the structural model, are minimal. However, all of the $A_{1}$ estimates, the parameter on $q_{t-1}$, are positive and in the unit interval. The parameter estimates on $\Delta p_{t},\left(A_{4}\right)$, are negative, as expected, with the sign determined by the price coefficient $\nu$ in the structural model equation (8). Finally, the parameter estimates on the income terms $A_{2}$ and $A_{3}$ are positive. Thus income levels and increments to income are positively related to consumption levels for the four aggregated commodity groups.

Results for the basic parameters of the dynamic linear expenditure system are shown in table 5. All regression coefficients are significantly different from zero at the $5 \%$ level, and all of the estimated coefficients have correct signs according to a priori reasoning. In general, the results for the basic parameters are quite favorable when compared with the theory and previous results for the United States (Phlips, 1974). 
Table 4. Estimates of Basic Parameters for the State Adjustment Model

\begin{tabular}{lcccccc}
\hline Commodity Group & $A_{0}$ & $A_{1}$ & $A_{2}$ & $A_{3}$ & $A_{4}$ & $A_{5}$ \\
\hline Durable Goods & 10.58 & .4843 & .3355 & .0879 & -223.63 & -58.59 \\
& & $(.1286)^{\mathrm{a}}$ & $(.0401)$ & $(.0268)$ & $(93.75)$ & \\
Semidurable Goods & 16.46 & .8448 & .1676 & .0164 & -93.65 & -9.16 \\
& & $(.0729)$ & $(.0169)$ & $(.0062)$ & $(52.29)$ & \\
Nondurable Goods & 245.85 & .6244 & .1590 & .0919 & -292.30 & -168.95 \\
& & $(.1771)$ & $(.0364)$ & $(.0428)$ & $(151.23)$ & \\
Services & 35.43 & .7550 & .2423 & .1174 & -138.03 & -66.87 \\
& & $(.2782)$ & $(.1003)$ & $(.1072)$ & $(436.73)$ & \\
\hline
\end{tabular}

a Standard errors are in parentheses.

Dynamic Systems: Structural Parameters and Elasticities

Estimates of the structural parameters and elasticities for the state adjustment model are presented in table 6 . There are two negative and two positive stock coefficients. This means that durable and semidurable goods with values for $\alpha_{i}$ less than zero are subject to inventory adjustment, while nondurables and services having $\alpha_{i}$ 's with positive signs are subject to habit formation. In each of the cases the results seem plausible.

Estimated values for the $\delta_{i}$ 's indicate rates of deterioration of from .10 for semidurables to .81 for nondurables. The estimated values for these structural parameters imply that habits in the case of nondurables and services deteriorate at faster rates than durable and semidurable goods depreciate. For each of the commodity groups, the short-run income coefficient $\kappa_{i}$ is positive and the short-run price coefficient $\nu_{i}$ negative.

For durable and semidurable goods the short-run income elasticity exceeds the longrun income elasticity. The converse is true for

Table 5. Estimates of Basic Parameters for Dynamic Linear Expenditure Model

\begin{tabular}{lcccc}
\hline $\begin{array}{l}\text { Commodity } \\
\text { Group }\end{array}$ & $k_{i 0}$ & $k_{i 1}$ & $k_{i 2}$ & $k_{i 3}$ \\
\hline Durables & 15.98 & .4332 & 156.32 & -114.72 \\
& & $(.0469)^{\mathrm{a}}$ & $(7.11)$ & $(9.24)$ \\
Semidurables & 15.38 & .8618 & 68.77 & -61.91 \\
& & $(.0568)$ & $(5.45)$ & $(6.76)$ \\
Nondurables & 146.63 & .5353 & 88.85 & -33.30 \\
& & $(.0842)$ & $(9.04)$ & $(16.0)$ \\
Services & 12.51 & .6978 & 121.35 & -47.74 \\
& & $(.0300)$ & $(13.0)$ & $(14.62)$ \\
\hline
\end{tabular}

a Standard errors are in parentheses. the short- and long-run elasticities for the nondurable goods and services commodity groups. This result is consistent with the Houthakker and Taylor rationalizations for inventory adjustment and habit formation. The direct price elasticities of demand have the anticipated negative signs and, as expected, price elasticities for the durable goods commodity groups are higher.

An examination of the structural coefficients for the dynamic linear expenditure system in table 7 reveals that all estimated depreciation rates $\delta_{i}$ 's are positive. In addition, they are plausible in magnitude, with larger values for nondurables (.90) and services $(.87)$ than for durables $(.30)$ and semidurables (.10). The higher depreciation rates for the nondurable and service groups reflect a lack of a strong persistence of habits. For durable goods, the rate of .30 implies that they are more than $90 \%$ depreciated by the end of seven years.

All of the estimated $\mu_{i}$ 's are positive, indicating a decreasing marginal utility for each commodity. Two of the commodity groups, durables and semidurables, have negative $\alpha_{i}$ 's indicating inventory adjustments. The remaining two commodity groups, nondurables and services, have positive estimated values for the $\alpha_{i}^{\prime}$ 's and thus are subject to habit formation. In every case the "autonomous necessary consumption level" $\theta_{i}$ is positive, with larger values for the semidurables and nondurables than for durables and services commodity groups. The adjustment coefficients $\rho_{i}$ are between zero and one in every case, indicating a partial adjustment mechanism for the state variables.

Estimated short- and long-run income elasticities are all positive. For the durables and semidurables commodity groups, the shortrun income elasticities $(3.13$ and 1.11 , respec- 
Table 6. Structural Coefficients and Elasticities for the State Adjustment Model

\begin{tabular}{|c|c|c|c|c|c|c|c|}
\hline \multirow[b]{2}{*}{ Commodity Group } & \multirow[b]{2}{*}{$\theta$} & \multirow[b]{2}{*}{$\alpha$} & \multirow[b]{2}{*}{$\kappa$} & \multirow[b]{2}{*}{$\nu$} & \multirow[b]{2}{*}{$\delta$} & \multicolumn{2}{|c|}{ Elasticities } \\
\hline & & & & & & Income & Price \\
\hline Durable Goods & 47.28 & -.393 & .3928 & -261.85 & .301 & $\begin{array}{ll}\text { SR } & 3.30 \\
\text { LR } & 1.43\end{array}$ & $\begin{array}{r}-1.31 \\
-.57\end{array}$ \\
\hline Semidurable Goods & 173.44 & -.065 & .1728 & -96.56 & .103 & $\begin{array}{lr}\text { SR } & 1.19 \\
\text { LR } & .73\end{array}$ & $\begin{array}{l}-.35 \\
-.21\end{array}$ \\
\hline Nondurable Goods & 372.36 & .350 & .1392 & -255.88 & .813 & $\begin{array}{ll}\text { SR } & .42 \\
\text { LR } & .74\end{array}$ & $\begin{array}{l}-.43 \\
-.76\end{array}$ \\
\hline Services & 63.14 & .360 & .2092 & -119.17 & .690 & $\begin{array}{lr}\text { SR } & .52 \\
\text { LR } & 1.19\end{array}$ & $\begin{array}{l}-.13 \\
-.31\end{array}$ \\
\hline
\end{tabular}

tively) are larger than the long-run income elasticities (1.09 and .71, respectively). The situation for the nondurables and services commodity groups is reversed, indicating habit formation. This effect is pronounced in the case of the services group, where the longand short-run elasticities estimates are 1.33 and .60 , respectively.

All the price elasticities have negative signs, with the compensated ones being the smaller. The uncompensated price elasticity estimates for durables $(-1.44)$ and semidurables $(-.671)$ are larger than those obtained from the state adjustment model. Lastly, in computing estimates, during the final iteration, the marginal utility of income, $\lambda$, declined in a continuous fashion with time. Because real income, in general, increased over the time period, this result corroborates the apparent reasonable estimates of the other structural parameters for the model.

The results in tables 6 and 7 can be compared with those in table 3 . The income elasticity for the durable goods commodity group in the static systems is about 1.4. This lies between the short- and long-run estimates of the income elasticity in the dynamic models, i.e., 1.4 to 3.3 for the state adjustment model and 1.1 to 3.1 for the dynamic linear expenditure system. Estimated short- and long-run income elasticities for the semidurable goods group are, if at all, only slightly higher for the dynamic than for static systems.

The price elasticity estimates from the static models are more comparable to those generated from the state adjustment model than the dynamic linear expenditure system. This could be because the latter provides added structure $\rho_{i}$. Generally, the results demonstrate that the adjustment, habit, and inventory features of the dynamic models have more plausibly captured the behavior of consumers. ${ }^{6}$ Values of short- and long-run, com-

\footnotetext{
${ }^{6}$ Additional estimates allowing for serial correlation (Berndt and Savin) in the errors for the static systems were computed Generally, the model with autocorrelated errors produced structural parameter estimates which were more variable but elasticities implied similar to the ones presented for the static systems. Apparently persistence in consumption patterns is best accommodated by allowing for it in the systematic portion of demand models.
}

Table 7. Structural Coefficients and Elasticities for the Dynamic Linear Expenditure Model

\begin{tabular}{|c|c|c|c|c|c|c|c|c|c|c|c|}
\hline \multirow[b]{2}{*}{ Commodity } & \multirow[b]{2}{*}{$\delta_{i}$} & \multirow[b]{2}{*}{$\mu_{i}$} & \multirow[b]{2}{*}{$\alpha_{i}$} & \multirow[b]{2}{*}{$\theta_{i}$} & \multirow[b]{2}{*}{$\rho_{i}{ }^{\mathrm{a}}$} & \multirow[b]{2}{*}{$\gamma_{i}{ }_{i}$} & \multirow[b]{2}{*}{$\mu^{*}{ }_{i}$} & & & \multicolumn{2}{|c|}{$\begin{array}{l}\text { Direct Price } \\
\text { Elasticity }\end{array}$} \\
\hline & & & & & & & & $\begin{array}{l}\text { Inc } \\
\text { Elas }\end{array}$ & $\begin{array}{l}\text { ome } \\
\text { ticity }\end{array}$ & $\begin{array}{l}\text { Uncom- } \\
\text { pensated }\end{array}$ & $\begin{array}{c}\text { Com- } \\
\text { pensated }\end{array}$ \\
\hline Durables & .30696 & 189.12 & -.4840 & 72.65 & .79096 & 28.19 & .15095 & $\begin{array}{l}\text { SR } \\
\text { LR }\end{array}$ & $\begin{array}{l}3.13 \\
1.09\end{array}$ & $\begin{array}{l}-1.44 \\
-0.89\end{array}$ & $\begin{array}{l}-1.01 \\
-0.74\end{array}$ \\
\hline Semidurables & .10498 & 70.19 & -.04347 & 157.36 & .14846 & 111.29 & .10289 & $\begin{array}{l}\text { SR } \\
\text { LR }\end{array}$ & $\begin{array}{l}1.11 \\
0.71\end{array}$ & $\begin{array}{l}-0.67 \\
-0.63\end{array}$ & $\begin{array}{l}-0.51 \\
-0.53\end{array}$ \\
\hline Nondurables & .90953 & 79.56 & .30435 & 210.04 & .60518 & 315.67 & .24590 & $\begin{array}{l}\text { SR } \\
\text { LR }\end{array}$ & $\begin{array}{l}0.53 \\
0.71\end{array}$ & $\begin{array}{l}-0.41 \\
-0.62\end{array}$ & $\begin{array}{l}-0.23 \\
-0.37\end{array}$ \\
\hline Services & .87049 & 99.59 & .51464 & 16.93 & .3559 & 41.41 & .50106 & $\begin{array}{l}\text { SR } \\
\text { LR }\end{array}$ & $\begin{array}{l}0.60 \\
1.33\end{array}$ & $\begin{array}{l}-0.49 \\
-0.97\end{array}$ & $\begin{array}{l}-0.27 \\
-0.47\end{array}$ \\
\hline
\end{tabular}

${ }^{\mathrm{a}} \rho_{i}=\delta_{i}-\alpha_{i}$. 
pensated and uncompensated price elasticities tend to bracket those obtained for the static models.

\section{Evaluation}

In addition to the comparisons made in the previous section, the results are evaluated relative to those obtained from another commodity grouping and other studies, as well as by the forecasting potential of the models. The alternative grouping of commodities is more disaggregated. The a vailable estimates of price and income elasticities provide a basis for evaluating the applied implications of different data bases, estimation methods, demand systems, and commodity groups. Finally, the forecasts within and outside of the sample period are made using the two dynamic models. These two dynamic models were selected for the forecasting exercise because the structural parameter estimates and elasticities reviewed in the previous section compared favorably to those from the static systems.

\section{Nine Commodity Groups}

Price and income elasticity estimates obtained by applying two of the static demand systems and the double log model to the Canadian data aggregated to nine commodity groups are contained in table $8 .^{7}$ The same exercise was attempted for the indirect addilog and dynamic demand systems. Unfortunately, the solutions were erratic or the models failed to converge, suggesting problems of multicollinearity or with the capacity of our computer programs for larger models. The double log estimates obtained without forcing the income elasticities to one are included to provide a contrast with the more theoretically consistent Rotterdam and linear expenditure systems. Comparative comments are confined to the Rotterdam and linear expenditure systems.

\footnotetext{
7 With only two exceptions, the groups of commodities and services are the same as used by Statistics Canada. The two exceptions are: (1) under the heading "Medical Care and Health Services," the components, medical care, hospital care, and other medical care expenses have been deleted. This deletion became necessary because of discontinuities in the series from 1961 due to the transfer of expenditures for non-profit hospitals from the personal sector to government and because, as various provincial administered medical care plans have come into effect beginning in 1962 and extending to 1971 , personal expenditures on medical services have shifted to current government expenditures from goods and services; (2) the second is deletion of "Net Expenditure Abroad." Since this is a residual item consisting of the balance of tourist revenue, it should not significantly alter the results.
}

In examining table 8 , attention is first drawn to the pattern of the estimated income elasticities. These results show that as for the four commodity groups, all income commodities are positive. For the Rotterdam and linear expenditure systems, commodity groups with an income elasticity less than unity are food, tobacco and alcoholic beverages, clothing, and personal goods and services. Consumption of these goods should tend to remain more stable for differing income levels. The results for food, in particular, are worth noting, because Engel's law concerning the decreasing share of expenditures on food with income increases is confirmed. Income elasticity estimates for housing and furniture are close to one. These commodity groups may, therefore, be viewed as luxuries, albeit moderate ones. The highest estimated income elasticities were obtained for transportation and recreation. As subsequently shown, for transportation this result is different than that obtained for the United States. Also, recall that for the commodity groups, transportation and recreation are highly influenced by durable goods purchases, a type of consumption behavior not especially well modeled by the static assumptions which underlie the results presented in table 8 .

In comparing the Rotterdam model income elasticities to those of the linear expenditure model, some differences are observed. For example, income elasticities for food, clothing, furniture, and transportation are slightly lower for the linear expenditure system than in the Rotterdam model. Income elasticities for tobacco and alcoholic beverages and drugs and sundries are almost identical in both models. This is in contrast to the results from the four-commodity case which showed the Rotterdam estimates with one exception uniformly higher.

Examination of the direct uncompensated price elasticity estimates in table 8 shows that all have the expected negative sign. Also, with five exceptions, the estimates have magnitudes which indicate an inelastic price response. The exception in the case of linear expenditure system is the recreation and entertainment commodity group where the required consumption level $\gamma$ was estimated as negative. For the Rotterdam model the estimated uncompensated price elasticities are 1.00 for transportation and communication and 1.09 for recreation and entertainment. The larger differences between the uncompensated price elasticity estimates for the Rotterdam 
Table 8. Comparison of Price and Income Elasticities Estimated for Different Static Models

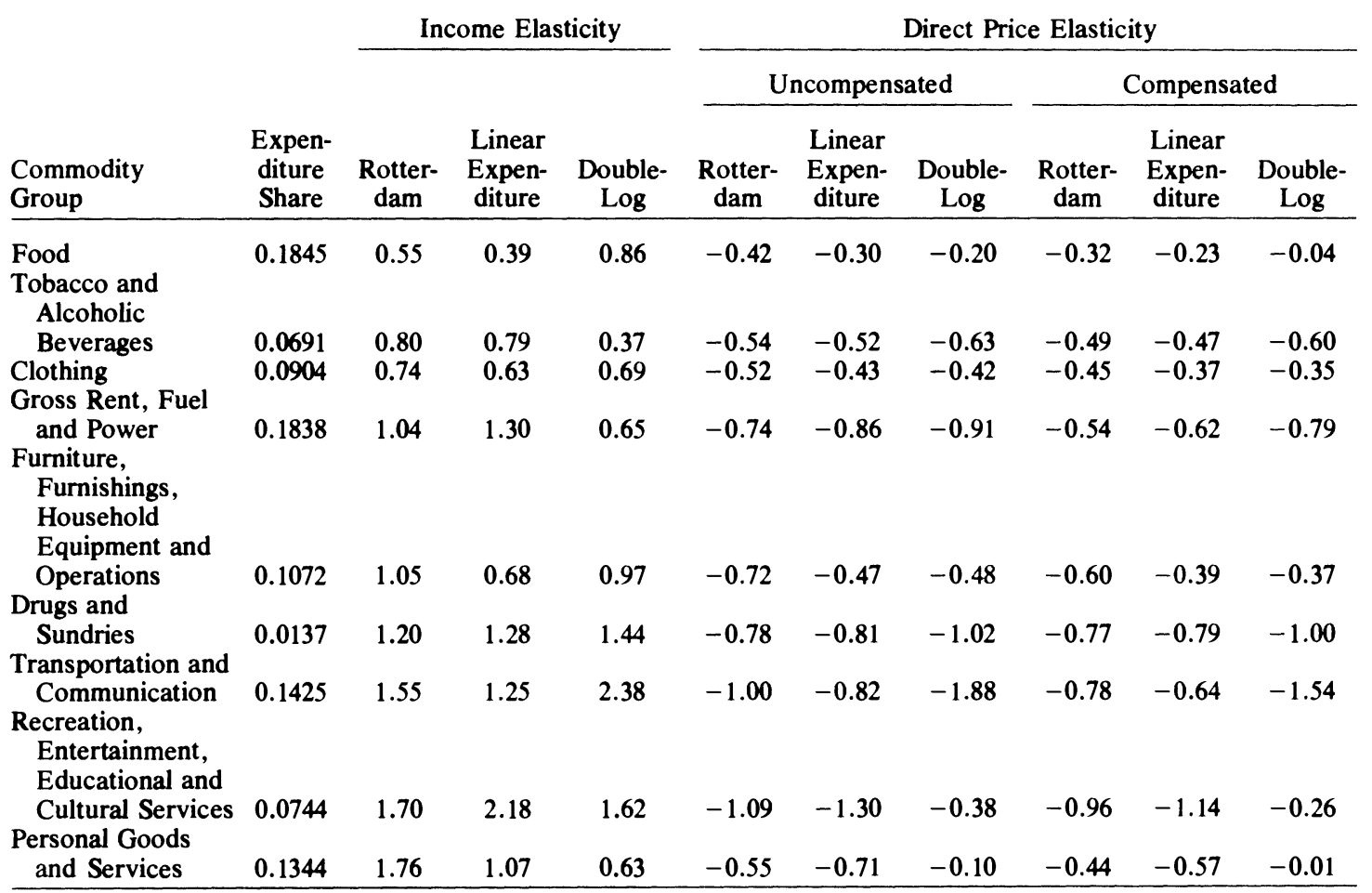

and linear expenditure models are for the furniture, furnishings, household equipment and operations, and the personal goods and services groups.

Generally, the estimates from the nine commodity groups appear supportive of the results and associated observations made for the application of the static models to the four commodity groups. The static models even at lower levels of disaggregation do not produce results which are as satisfactory for commodity groups made up of durable goods, as do the dynamic models. For example, in the cases of the furniture, furnishings, household equipment and operation group and the transportation group, the income and price elasticities obtained show comparatively large differences between the Rotterdam and linear expenditure system estimates and those for durable goods obtained when the dynamic models were applied for four commodity groups. Although the overlap in classes is not complete, the stability of the estimates between the dynamic systems and their discrepancies between the static models would suggest some improvement resulted from the more flexible structures.

\section{Estimates From Other Studies}

Comparisons of the estimates for the four and nine commodity cases to those from other studies must be made with caution since the latter involve different models, data bases, estimation methods, and commodity groups. Results of the studies, however, can be evaluated in relation to their implications for policy purposes. For the present evaluation, results for income and price elasticities from several studies using Canadian and United States data have been assembled in table 9. (Other studies using Canadian data include Carlevaro, Goldberger and Gameltsos, Oksanen and Spencer, and Schweitzer.) The table includes a citation and information on the country, the time period of application, the demand system employed, the commodity groups, and the elasticity estimates.

The comparisons afforded by the information in tables $3,6,7,8$, and 9 are obviously numerous. The income elasticity estimates for food from the present analysis and among the other studies are quite similar. Food is income inelastic with a coefficient in the range .31 to .64. In the four commodity group models, food 


\begin{tabular}{|c|c|c|c|c|c|}
\hline \multirow[b]{2}{*}{ Study } & \multirow[b]{2}{*}{$\begin{array}{c}\text { Time Period/ } \\
\text { Country }\end{array}$} & \multirow[b]{2}{*}{ Demand System $^{a}$} & \multirow[b]{2}{*}{ Commodity Group } & \multicolumn{2}{|c|}{ Elasticity } \\
\hline & & & & Price & Income \\
\hline Powell (1965) & $\begin{array}{c}\text { 1949-1963/ } \\
\text { Canada }\end{array}$ & $\begin{array}{l}\text { Additive } \\
\text { Preference }\end{array}$ & $\begin{array}{l}\text { Food } \\
\text { Tobacco \& Alcoholic Beverages } \\
\text { Clothing } \\
\text { Shelter } \\
\text { Household Expenses } \\
\text { Transportation } \\
\text { Personal, Medical } \\
\text { Miscellaneous }\end{array}$ & $\begin{array}{r}-0.46 \\
-0.54 \\
-0.52 \\
-0.38 \\
-1.28 \\
-1.37 \\
0.05 \\
-0.67\end{array}$ & $\begin{array}{r}0.58 \\
0.79 \\
0.74 \\
0.51 \\
2.13 \\
2.32 \\
-0.07 \\
0.97\end{array}$ \\
\hline Wales & $\begin{array}{c}\text { 1947-1968/ } \\
\text { Canada }\end{array}$ & LES & $\begin{array}{l}\text { Food } \\
\text { Clothing } \\
\text { Shelter } \\
\text { Miscellaneous }\end{array}$ & $\begin{array}{l}-0.27^{b} \\
(-0.39)^{c} \\
-0.24 \\
(-0.31) \\
-0.81 \\
(-0.20) \\
-1.02 \\
(-0.71)\end{array}$ & $\begin{array}{c}0.31^{\mathrm{b}} \\
(0.86)^{\mathrm{c}} \\
0.33 \\
(0.95) \\
1.14 \\
(0.42) \\
1.67 \\
(1.52)\end{array}$ \\
\hline McIntosh & $\begin{array}{c}\text { 1949-1968/ } \\
\text { Canada }\end{array}$ & LES & $\begin{array}{l}\text { Food } \\
\text { Clothing } \\
\text { Housing } \\
\text { Transportation \& Communication } \\
\text { Recreation, Education \& } \\
\text { Entertainment } \\
\text { Health } \\
\text { Miscellaneous }\end{array}$ & $\begin{array}{r}-0.26 \\
-0.22 \\
-0.67 \\
-0.59 \\
-0.58 \\
0.35 \\
-0.70\end{array}$ & $\begin{array}{r}0.45 \\
0.51 \\
1.30 \\
1.41 \\
\\
1.19 \\
-0.69 \\
1.39\end{array}$ \\
\hline $\begin{array}{l}\text { Berndt, Darrough } \\
\text { \& Diewert }\end{array}$ & $\begin{array}{l}\text { 1952-1971/ } \\
\text { Canada }\end{array}$ & TLOG & $\begin{array}{l}\text { Durables } \\
\text { Non-Durables \& Semi-Durables } \\
\text { Services }\end{array}$ & $\begin{array}{l}-1.18 \\
-0.68 \\
-0.42\end{array}$ & $\begin{array}{r}1.59 \\
.35 \\
1.61\end{array}$ \\
\hline $\begin{array}{l}\text { Hassan, Johnson } \\
\text { \& Finley }\end{array}$ & $\begin{array}{c}\text { 1929-1969/ } \\
\text { USA }\end{array}$ & Rotterdam & $\begin{array}{l}\text { Durable Goods } \\
\text { Food } \\
\text { Clothing \& Shoes } \\
\text { Gasoline \& Oil } \\
\text { Other Non-Durable Goods } \\
\text { Housing } \\
\text { Household Operation } \\
\text { Transportation } \\
\text { Other Services }\end{array}$ & $\begin{array}{l}-0.86 \\
-0.33 \\
-0.44 \\
-0.28 \\
-0.47 \\
-0.20 \\
-0.33 \\
-0.36 \\
-0.32\end{array}$ & $\begin{array}{l}2.43 \\
0.64 \\
1.13 \\
0.79 \\
1.15 \\
0.46 \\
0.89 \\
1.04 \\
0.71\end{array}$ \\
\hline $\begin{array}{l}\text { Weiserbs } \\
\text { (Phlips (1974)) }\end{array}$ & $\begin{array}{c}\text { 1929-1970/ } \\
\text { USA }\end{array}$ & LES-D & $\begin{array}{l}\text { Automobiles \& Parts } \\
\text { Furniture \& Household } \\
\text { Equipment } \\
\text { Other Durable Goods } \\
\text { Food \& Beverages } \\
\text { Clothing \& Shoes } \\
\text { Gasoline \& Oil } \\
\text { Other Non-Durable Goods } \\
\text { Housing } \\
\text { Household Operation } \\
\text { Transportation } \\
\text { Other Services }\end{array}$ & $\begin{array}{l}-2.13^{\mathrm{d}} \\
(-1.35)^{\mathrm{e}} \\
-0.89 \\
(-0.90) \\
-0.48 \\
(-1.50) \\
-0.30 \\
(-0.53) \\
-0.47 \\
(-0.97) \\
-0.15 \\
(-1.17) \\
-0.33 \\
(-0.92) \\
-0.12 \\
(-1.43) \\
-0.24 \\
(-1.38) \\
-0.31 \\
(-0.87) \\
-0.27 \\
(0.85)\end{array}$ & $\begin{array}{c}7.57^{\mathrm{d}} \\
(1.65)^{\mathrm{e}} \\
2.35 \\
(0.92) \\
1.27 \\
(1.88) \\
0.53 \\
(0.58) \\
1.11 \\
(1.04) \\
0.36 \\
(1.76) \\
0.76 \\
(1.21) \\
0.24 \\
(3.49) \\
0.58 \\
(2.23) \\
0.80 \\
(1.03) \\
0.56 \\
(-0.99)\end{array}$ \\
\hline Lluch \& Williams & $\begin{array}{c}\text { 1930-1972/ } \\
\text { USA }\end{array}$ & LES & $\begin{array}{l}\text { Food } \\
\text { Clothing } \\
\text { Housing } \\
\text { Durables } \\
\text { Other }\end{array}$ & $\begin{array}{l}-0.28 \\
-0.48 \\
-0.61 \\
-0.83 \\
-0.74\end{array}$ & $\begin{array}{l}0.41 \\
0.90 \\
1.13 \\
1.61 \\
1.13\end{array}$ \\
\hline
\end{tabular}

a LES denotes linear expenditure system. LES-D indicates linear expenditure system-dynamic. TLOC denotes translog reciprocal indirect utility function.

' Linear expenditure system "static."

c Linear expenditure system "habit formation."

d Short run estimates.

e Long run estimates. 
is in the class of nondurables. Our estimates of income elasticities for this nondurables commodity group show the short- and longrun income elasticities ranging from about .4 to .7 , the latter being the long-run estimate. This compares to an income estimate of .68 obtained for a non- and semidurables class by Berndt, Darrough, and Diewert.

In the case of clothing, our income elasticity estimates are consistent with those of Powell, Wales, and McIntosh for Canada. However, they are lower than those published by Hassan, Johnson, and Finley; Weiserbs; and Lluch and Williams for the United States. The semidurables in the four commodity group models have somewhat higher income elasticities than those reported for clothing. This is true even of the state adjustment and dynamic linear expenditure models, which suggest a range of .7 to 1.2 for short- and long-run income elasticities for semi-durables.

For both shelter and transportation, the estimates from the present analysis are in general agreement with those in table 9. Our results and those in table 9 show a systematic difference between the United States and Canada in income elasticity for transportation. This may be due to subsidies in the United States and the excise tax in Canada. On a more general level, the durable goods group estimates in table 9 and our own estimates for this commodity group indicate a similar income elasticity. Again, the flexibility of the dynamic models is suggested by the fact that the income elasticity estimates for durables in tables 6 and 7 bound most of those reported in table 9.

Price elasticity estimates seem to be roughly similar for food, clothing, and durable goods. This is especially true of those estimates obtained from the linear expenditure system and the indirect addilog models. In the case of durable goods, elasticities estimated from the static models lie between those for durable goods from the two dynamic models. Finally, for shelter, the own price elasticities differ from those in table 9. However, the source of the difference appears due more to the variable results obtained in other studies than as a systematic effect in our data or models.

\section{Forecasting Performance}

As a last evaluative exercise, the forecasts from the two dynamic models are examined. Data for estimating the models were for 1947-1972. The outside sample data used $(1973,1974)$ are revised series obtained from Statistics Canada, and the revisions were substantial for the services group. These revised values were used without adjustment for simulating the model, perhaps causing some discrepancy. The model was not reestimated since the revised data series is presently not of sufficient length.

Forecasts or simulations were calculated using actual revised initial values of the lagged endogenous variables. Simulated values were used after the models were initialized at the first period, and there was no calibration to insure better fits. Most of the turning points were properly reflected, and there were few major discrepancies in the levels of the actual and simulated expenditures. These observations are borne out in table 10 , which contains the root mean square error (absolute and percentage) for the models in and outside the sample period. Generally, the within and outside sample period results suggest the same conclusions. The dynamic linear expenditure system produces the better fit. Errors are largest for services and smallest for nondurable goods outside the sample period, but largest for durables within the sample period. The former discrepancy could be caused by the revisions in the data series.

Table 10. Evaluative Statistics for the Simulation of the Dynamic Models

\begin{tabular}{|c|c|c|c|c|c|c|c|c|}
\hline \multirow[b]{3}{*}{ Commodity Group } & \multicolumn{4}{|c|}{ State Adjustment Model } & \multicolumn{4}{|c|}{ Linear Expenditure-Dynamic } \\
\hline & \multicolumn{2}{|c|}{$\begin{array}{c}\text { RMS } \\
\text { (Error) }\end{array}$} & \multicolumn{2}{|c|}{$\begin{array}{c}\text { RMS } \\
\text { (Percent Error) }\end{array}$} & \multicolumn{2}{|c|}{$\begin{array}{c}\text { RMS } \\
\text { (Error) }\end{array}$} & \multicolumn{2}{|c|}{$\begin{array}{c}\text { RMS } \\
\text { (Percent Error) }\end{array}$} \\
\hline & $47-72$ & $73-74$ & $47-72$ & $73-74$ & $47-72$ & $73-74$ & $47-72$ & $73-74$ \\
\hline Durable Goods & $8.56^{\mathrm{a}}$ & $28.60^{\mathrm{b}}$ & 4.24 & 5.86 & 6.50 & 10.14 & 2.93 & 2.13 \\
\hline Semidurable Goods & 3.87 & 18.03 & 1.25 & 4.34 & 2.87 & 12.01 & 1.03 & 2.88 \\
\hline Nondurable Goods & 7.00 & 11.07 & 1.03 & 1.24 & 7.31 & 13.11 & 1.05 & 1.46 \\
\hline Services & 15.21 & 42.41 & 1.89 & 3.72 & 14.98 & 42.62 & 1.67 & 3.73 \\
\hline
\end{tabular}

${ }^{a}$ Inside the sample period.

b Outside the sample period and with unincorporated revisions of the services series. 


\section{Conclusion}

Generally, there is a substantial degree of similarity between the estimates obtained in this analysis, even between static and dynamic models. The static models, except for the double $\log$, produced estimates which had similar implications and compared favorably with those summarized from other studies when the latter were themselves not erratic. Of the two dynamic models, the linear expenditure system performed better by comparison to results from other studies and on the basis of the within and outside sample simulations. This improved performance is possibly a result of the more flexible adjustment mechanism that the linear expenditure system incorporates. Generally, the plausible adjustment implications and the estimated long-run price effects compared to those for the static models provide an empirical impetus for attempting to extend models of the structure of consumer behavior to more dynamic settings.

\section{[Received March 1977; revision accepted September 1977.]}

\section{References}

Barten, A. P. "The Systems of Consumer Demand Functions Approach: A Review." Econometrica 45 (1977):23-51.

- "Consumer Demand Functions under Conditions of Almost Additive Preference." Econometrica 32 (1964):1-38.

_. "Estimating Demand Equations." Econometrica 36 (1968):213-251.

- "Maximum Likelihood Estimation of a Complete System of Demand Equations." Europ. Econ. Rev. 1 (1969):7-73.

Berndt, E. R., M. N. Darrough, and W. E. Diewert. "Flexible Functional Forms and Expenditure Distributions: An Application to Canadian Consumer Demand Functions.' Discussion Paper 77-10, Dep. Econ., University of British Columbia, 1977.

Berndt, E. R., and N. E. Savin. "Estimation and Hypothesis Testing in Singular Equation Systems with Autoregressive Disturbances." Econometrica 43 (1975): 937-57.

Carlevaro, F. "Specifications and Estimation of Partially Aggregated Consumption Functions.' Can. J. Econ. 4 (1971):441-470.

Carlevaro, F., and E. Sadoulet. Three Programs for the Estimation of a General Class of Additive Consumption Functions. Geneva, Switzerland: University of Geneva, 1973.

Frisch, R. A. "A Complete Scheme for Computing All Direct and Cross Demand Elasticities in a Model with Many Sectors.' Econometrica 27 (1959):177-96.
Goldberger, A. S., and T. Gameltsos. "A Cross Country Comparison of Consumer Expenditure Patterns." Europ. Econ. Rev. 1 (1970):357-400.

Hassan, Z. A., S. R. Johnson, and R. M. Finley. "Further Evidence of the Structure of Consumer Demand in the U.S.: An Application of the Separability Hypothesis." S. Econ. J. 41 (1974):244-57.

Houthakker, H. S. "Additive Preferences." Econometrica 28 (1960):244-257.

Houthakker, H. S., and L. D. Taylor. Consumer Demand in the United States, 2nd ed. Cambridge, Mass.: Harvard University Press, 1970.

Klein, L. R., and H. Rubin. "A Constant Utility Index of the Cost of Living." Rev. Econ. Stud. 15 (19471948):84-87.

Lluch, C. "The Extended Linear Expenditure System." Europ. Econ. Rev. 15 (1973):21-32.

- "Expenditure, Savings and Habit Formation." Int. Econ. Rev. 15 (1974):786-97.

Lluch, C., and R. Williams. "Consumer Demand Systems and Aggregate Consumption in the U.S.A.: An Application of the Extended Linear Expenditure System." Can. J. Econ. 8 (1975):49-66.

McIntosh, C. E. "Canadian Food Expenditures in 1980." Can. J. Agr. Econ. 22 (1974):45-51.

Oksanen, E. H., and B. T. Spencer. "Testing an Aggregate Consumption Model for Canada." Can.J. Econ. 5 (1972):96-109.

Parks, R. W. "Maximum Likelihood Estimation of the Linear Expenditure System.' J. Amer. Statist. Ass. 66 (1971):900-903.

Phlips, L. "A Dynamic Version of the Linear Expenditure Model." Rev. Econ. and Statist. 64 (1972):450-58. . Applied Consumption Analysis. Amsterdam: North-Holland Publishing Co., 1974.

Powell, A. A. "A Complete System of Consumer Demand Equations for the Australian Economy Fitted by a Model of Additive Preferences." Econometrica 34 (1966):661-75.

. "Post-War Consumption in Canada: A First Look at Aggregates." Can. J. Econ. and Polit. Sci. 31 (1965):559-65.

- Empirical Analytics and Demand Systems. Lexington, Mass.: D.C. Heath and Co., 1974.

Schweitzer, T. T. "Personal Consumer Expenditures in Canada 1926-75," parts I, II, III. Staff Study No. 26, Economic Council of Canada, Ottawa, Mar. 1971.

Statistics Canada. National Income and Expenditures Accounts. Catalogue 13-351, Ottawa, 1975.

Stone, R. "Linear Expenditure Systems and Demand Analysis: An Application to the Pattern of British Demand.' Econ. J. 64 (1954):511-27.

Theil, H. Economics and Information Theory. Amsterdam: North-Holland Publishing Co., 1967.

- Principles of Econometrics. New York: John Wiley and Sons, 1971.

Wales, T. J. "A Generalized Linear Expenditure Model of the Demand for Non-Durable Goods in Canada." Can. J. Econ. 4 (1971):471-84.

Yoshihara, K. "Demand Functions: An Application to the Japanese Expenditure Pattern. Econometrica 37 (1969):257-74. 
http://www.jstor.org

\title{
LINKED CITATIONS
}

- Page 1 of 5 -

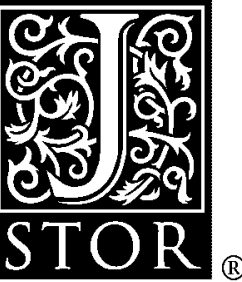

You have printed the following article:

\author{
Alternative Estimates of Static and Dynamic Demand Systems for Canada \\ Richard Green; Zuhair A. Hassan; S. R. Johnson \\ American Journal of Agricultural Economics, Vol. 60, No. 1. (Feb., 1978), pp. 93-107. \\ Stable URL: \\ http://links.jstor.org/sici?sici=0002-9092\%28197802\%2960\%3A1\%3C93\%3AAEOSAD\%3E2.0.CO\%3B2-6
}

This article references the following linked citations. If you are trying to access articles from an off-campus location, you may be required to first logon via your library web site to access JSTOR. Please visit your library's website or contact a librarian to learn about options for remote access to JSTOR.

\section{[Footnotes]}

\author{
${ }^{3}$ A Complete System of Consumer Demand Equations for the Australian Economy Fitted by a \\ Model of Additive Preferences \\ Alan Powell \\ Econometrica, Vol. 34, No. 3. (Jul., 1966), pp. 661-675. \\ Stable URL: \\ http://links.jstor.org/sici?sici=0012-9682\%28196607\%2934\%3A3\%3C661\%3AACSOCD\%3E2.0.CO\%3B2-M

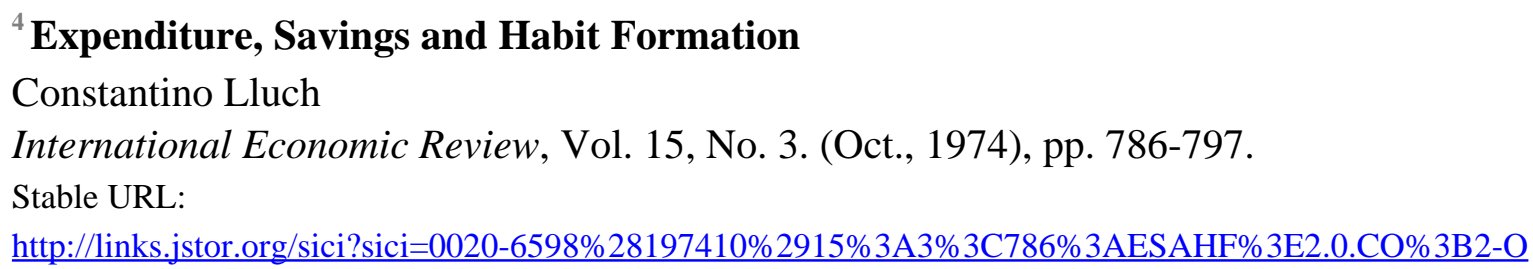

\section{References}

The Systems of Consumer Demand Functions Approach: A Review

Anton P. Barten

Econometrica, Vol. 45, No. 1. (Jan., 1977), pp. 23-50.

Stable URL:

http://links.jstor.org/sici?sici=0012-9682\%28197701\%2945\%3A1\%3C23\%3ATSOCDF\%3E2.0.CO\%3B2-B

NOTE: The reference numbering from the original has been maintained in this citation list. 
http://www.jstor.org

\section{LINKED CITATIONS}

- Page 2 of 5 -

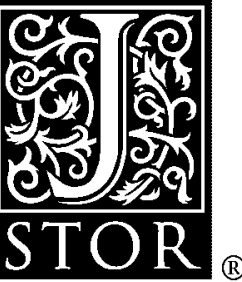

Consumer Demand Functions under Conditions of Almost Additive Preferences

A. P. Barten

Econometrica, Vol. 32, No. 1/2. (Jan. - Apr., 1964), pp. 1-38.

Stable URL:

http://links.jstor.org/sici?sici=0012-9682\%28196401\%2F04\%2932\%3A1\%2F2\%3C1\%3ACDFUCO\%3E2.0.CO\%3B2-K

Estimating Demand Equations

A. P. Barten

Econometrica, Vol. 36, No. 2. (Apr., 1968), pp. 213-251.

Stable URL:

http://links.jstor.org/sici?sici=0012-9682\%28196804\%2936\%3A2\%3C213\%3AEDE\%3E2.0.CO\%3B2-J

Estimation and Hypothesis Testing in Singular Equation Systems with Autoregressive Disturbances

Ernst R. Berndt; N. Eugene Savin

Econometrica, Vol. 43, No. 5/6. (Sep. - Nov., 1975), pp. 937-958.

Stable URL:

http://links.jstor.org/sici?sici=0012-9682\%28197509\%2F11\%2943\%3A5\%2F6\%3C937\%3AEAHTIS\%3E2.0.CO\%3B2-7

\section{Specification and Estimation of Systems of Consumption Functions}

F. Carlevaro

The Canadian Journal of Economics / Revue canadienne d'Economique, Vol. 4, No. 4. (Nov., 1971), pp. 441-470.

Stable URL:

http://links.jstor.org/sici?sici=0008-4085\%28197111\%294\%3A4\%3C441\%3ASAEOSO\%3E2.0.CO\%3B2-M

A Complete Scheme for Computing All Direct and Cross Demand Elasticities in a Model with Many Sectors

Ragnar Frisch

Econometrica, Vol. 27, No. 2. (Apr., 1959), pp. 177-196.

Stable URL:

http://links.jstor.org/sici?sici=0012-9682\%28195904\%2927\%3A2\%3C177\%3AACSFCA\%3E2.0.CO\%3B2-J

NOTE: The reference numbering from the original has been maintained in this citation list. 
http://www.jstor.org

\section{LINKED CITATIONS}

- Page 3 of 5 -

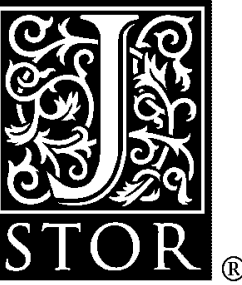

Further Evidence on the Structure of Consumer Demand in the U. S.: An Application of the Separability Hypothesis

Zuhair A. Hassan; S. R. Johnson; Robert M. Finley

Southern Economic Journal, Vol. 41, No. 2. (Oct., 1974), pp. 244-257.

Stable URL:

http://links.jstor.org/sici?sici=0038-4038\%28197410\%2941\%3A2\%3C244\%3AFEOTSO\%3E2.0.CO\%3B2-V

\section{Additive Preferences}

H. S. Houthakker

Econometrica, Vol. 28, No. 2. (Apr., 1960), pp. 244-257.

Stable URL:

http://links.jstor.org/sici?sici=0012-9682\%28196004\%2928\%3A2\%3C244\%3AAP\%3E2.0.CO\%3B2-K

\section{Expenditure, Savings and Habit Formation}

Constantino Lluch

International Economic Review, Vol. 15, No. 3. (Oct., 1974), pp. 786-797.

Stable URL:

http://links.jstor.org/sici?sici=0020-6598\%28197410\%2915\%3A3\%3C786\%3AESAHF\%3E2.0.CO\%3B2-O

Consumer Demand Systems and Aggregate Consumption in the USA: An Application of the Extended Linear Expenditure System

C. Lluch; R. Williams

The Canadian Journal of Economics / Revue canadienne d'Economique, Vol. 8, No. 1. (Feb., 1975), pp. 49-66.

Stable URL:

http://links.jstor.org/sici?sici=0008-4085\%28197502\%298\%3A1\%3C49\%3ACDSAAC\%3E2.0.CO\%3B2-Y

\section{Testing an Aggregate Consumption Model for Canada}

Ernest H. Oksanen; Byron G. Spencer

The Canadian Journal of Economics / Revue canadienne d'Economique, Vol. 5, No. 1. (Feb., 1972), pp. 96-109.

Stable URL:

http://links.jstor.org/sici?sici=0008-4085\%28197202\%295\%3A1\%3C96\%3ATAACMF\%3E2.0.CO\%3B2-N

NOTE: The reference numbering from the original has been maintained in this citation list. 
http://www.jstor.org

\title{
LINKED CITATIONS
}

- Page 4 of 5 -

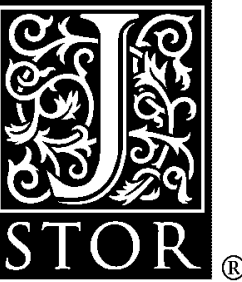

\author{
Maximum Likelihood Estimation of the Linear Expenditure System \\ Richard W. Parks \\ Journal of the American Statistical Association, Vol. 66, No. 336. (Dec., 1971), pp. 900-903. \\ Stable URL: \\ http://links.jstor.org/sici?sici=0162-1459\%28197112\%2966\%3A336\%3C900\%3AMLEOTL\%3E2.0.CO\%3B2-V
}

\author{
A Dynamic Version of The Linear Expenditure Model \\ Louis Phlips \\ The Review of Economics and Statistics, Vol. 54, No. 4. (Nov., 1972), pp. 450-458. \\ Stable URL: \\ http://links.jstor.org/sici?sici=0034-6535\%28197211\%2954\%3A4\%3C450\%3AADVOTL\%3E2.0.CO\%3B2-G
}

A Complete System of Consumer Demand Equations for the Australian Economy Fitted by a Model of Additive Preferences

Alan Powell

Econometrica, Vol. 34, No. 3. (Jul., 1966), pp. 661-675.

Stable URL:

http://links.jstor.org/sici?sici=0012-9682\%28196607\%2934\%3A3\%3C661\%3AACSOCD\%3E2.0.CO\%3B2-M

\section{Post-War Consumption in Canada: A First Look at the Aggregates}

Alan Powell

The Canadian Journal of Economics and Political Science / Revue canadienne d'Economique et de Science politique, Vol. 31, No. 4. (Nov., 1965), pp. 559-565.

Stable URL:

http://links.jstor.org/sici?sici=0315-4890\%28196511\%2931\%3A4\%3C559\%3APCICAF\%3E2.0.CO\%3B2-O

\author{
Linear Expenditure Systems and Demand Analysis: An Application to the Pattern of British \\ Demand \\ Richard Stone \\ The Economic Journal, Vol. 64, No. 255. (Sep., 1954), pp. 511-527. \\ Stable URL: \\ http://links.jstor.org/sici?sici=0013-0133\%28195409\%2964\%3A255\%3C511\%3ALESADA\%3E2.0.CO\%3B2-D
}

NOTE: The reference numbering from the original has been maintained in this citation list. 
http://www.jstor.org

\section{LINKED CITATIONS \\ - Page 5 of 5 -}

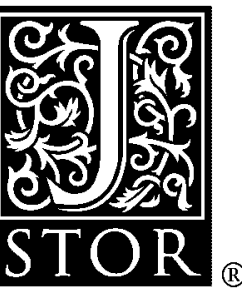

\section{A Generalized Linear Expenditure Model of the Demand for Non-Durable Goods in Canada} Terence J. Wales

The Canadian Journal of Economics / Revue canadienne d'Economique, Vol. 4, No. 4. (Nov., 1971), pp. 471-484.

Stable URL:

http://links.jstor.org/sici?sici=0008-4085\%28197111\%294\%3A4\%3C471\%3AAGLEMO\%3E2.0.CO\%3B2-5

Demand Functions: An Application to the Japanese Expenditure Pattern

Kunio Yoshihara

Econometrica, Vol. 37, No. 2. (Apr., 1969), pp. 257-274.

Stable URL:

http://links.jstor.org/sici?sici=0012-9682\%28196904\%2937\%3A2\%3C257\%3ADFAATT\%3E2.0.CO\%3B2-4

NOTE: The reference numbering from the original has been maintained in this citation list. 